\title{
The Bible in Africa: a novel usage in Africa's new churches
}

\author{
Paul Gifford
}

School of Oriental and African Studies

pg@soas.ac.uk

\begin{abstract}
To the extent there is an African academic approach, it is comparative (showing that the African world has similarities with the biblical). There are some "post-colonial" and similar readings, but this academic study is in the main done by Western-trained academics and directed at Western readers. There has been relatively little study of the way the Bible is actually used in churches, especially at the very grassroots. In mainline churches, the Bible is generally taken (as in the West) as a book of revelation which the preacher must expound and apply. In the new fast-growing Pentecostal sector the Bible is conceived quite differently, and understood as a record of covenants, promises, pledges and commitments between God and his chosen. It is not just a record of covenants and commitments to others in the past. It is not primarily a historical document at all. It is a contemporary document; it tells of God's covenant with and commitment to me, and to me now. These promises in scripture are effected in believers' lives through proclamation. The major biblical motifs in this emerging Christianity are thus those stressing victory, success, hope, achievement. The texts that are dominant are therefore prophetic texts, and narratives of those who can be made to illustrate success.
\end{abstract}

The Bible is a controversial document in Africa. Africa's traumatic encounter with the West led not only to a loss of political control, but also to a damaged self-understanding. Independent Africa's preoccupations were to resist continued Western economic domination, and assert African identity over the West, especially by affirming its identity with Africa's traditional heritage and resisting Western intellectual hegemony. So in the second half of the twentieth century, this issue of African authenticity and self-reliance, coupled with a comprehensive critique of the West and its role in Africa, has been the principal dynamic of Africa's intellectual life in all fields, not least theology. Of course, this did not go unchallenged - African Marxists like Fanon claimed that variations of this "Negritude" constituted a blind alley; it might satisfy one craving of the African soul, but only political liberation and total social restructuring could guarantee Africa's future. African Christian theologians accepted, too, the assumption of African intellectuals that Christianity was an integral part of the West's assault on Africa. So African theology came to revolve around two poles: first to rehabilitate African culture and religion, and second, to critique the Western impact on Africa, not 
least that of the missionaries, and naturally their Bible. ${ }^{1}$ So although there is no one method of studying the Bible in Africa, this is one of the most dominant strands, particularly evident in South and East Africa: to question its role as an instrument of oppression, dispossession and alienation. In South African theological circles, Afrikaner historical criticism, which left unchallenged even if it did not support apartheid, has been a particular focus of attack. ${ }^{2}$

This ambivalence has at its extreme led to a rejection of the Bible, even to the extent of creating a new scripture specially for Africa, intended to replace the Bible which is considered the scripture for Europeans. ${ }^{3}$ More commonly, though, it has led to an interpretation of the Bible in relation to African culture, what has been called the comparative method, in which biblical texts or motifs are compared to African parallels, letting the two illuminate each other. Such studies form the great bulk of all African biblical interpretation. This comparative method, however, has changed over time. In its earliest phase (1930s to 1970s) the aim was to legitimate African religion and culture in relation to the Western tradition. In the next

1 For this, see Paul Bowers, "African theology: its history, dynamics, scope and future", Africa Journal of Evangelical Theology 21/2, 2002, 109-25.

2 For examples of African biblical interpretation, see Hannah W. Kinoti and John M. Waliggo (eds), The Bible in African Christianity: Essays in Biblical Theology (Nairobi: Acton, 1997); Gerald O. West and Musa W. Dube, The Bible in Africa: Transactions, Trajectories and Trends (Leiden: Brill, 2000); Ukachukwu Chris Manus, Intercultural Hermeneutics in Africa (Nairobi: Acton, 2003); Jean-Claude Loba-Mkole and Ernst R. Wendland, Interacting with Scriptures in Africa (Nairobi: Acton, 2005); Mary N. Getui, Knut Holter and Victor Zinkuratire (eds), Interpreting the Old Testament in Africa (Nairobi: Acton, 2001); Mary N. Getui, Tinyiko Maluleke and Justin Ukpong (eds), Interpreting the New Testament in Africa (Nairobi: Acton, 2001); Hilary B. P. Mijoga, Preaching and the Bible in African Churches (Nairobi: Acton, 2001); Ernst R. Wendland and Jean-Claude Loba-Mkole, Biblical Texts and African Audiences (Nairobi: Acton, 2004); J.N.K. Mugambi and Johannes A. Smit, Text and Context in New Testament Hermeneutics (Nairobi: Acton, 2004); M.T. Speckman, The Bible and Human Development in Africa (Nairobi: Acton, 2001); Knut Holter (ed.), Let My People Stay! Researching the Old Testament in Africa (Nairobi: Acton, 2006); Tukonboh Adeyemo (ed.), Africa Bible Commentary (Nairobi: Word Alive Publishers, 2006); Jean-Bosco Matand Bulembat (ed.), Sagesse humaine et sagesse divine dans la Bible: mélanges offerts à S.E. Laurent Monsengwo Pasinya à l'occasion de ses 25 ans d'episcopat (Nairobi: Paulines, 2007); J. O. Akao, D. O. Akinntunde, G. N. Toryough, P. A. Oguntoye and M. I. Oguntoyinbo-Atere (eds), Decolonization of Biblical Interpretation in Africa (Ibadan: Nigerian Association for Biblical Studies, 2005); Musa W. Dube, Other Ways of Reading: African Women and the Bible (Atlanta: SBL, 2001); Itumeleng J. Mosala, Biblical Hermeneutics and Black Theology in South Africa (Grand Rapids: Eerdmans, 1989); Gerald O. West, The Academy of the Poor: Towards a Dialogical Reading of the Bible (Sheffield: Sheffield University Press, 1999).

3 Kofi Ameve, The Divine Acts: Holy Scriptures for Sankofa Faith (Accra: Afrikania, n.d.) is a Bible devised for the West African Afrikania faith, an attempt to raise African religion to the status of a world religion. Ka: the Holy book of Neter (Nairobi: Africa Comb Books, 2005) is another scripture devised for Africa, precisely to replace any imported scripture like the Bible. It must be said, however, that these and similar attempts are decidedly minority pursuits. 
phase (1970s to 1990s) the African reality became more central as a resource for biblical interpretation. In its current phase (since the 1990s) the African reality is foregrounded as the explicit focus of biblical interpretation, with the biblical parallel serving to illuminate the African reality. ${ }^{4}$ Currently, much African theology (and biblical study) has come to turn on African culture. ${ }^{5}$ In many cases, this involves rejecting the staple Western approach to biblical study, the historical or historical-critical method, as irredeemably Eurocentric. This has led to some (though remarkably few) "postcolonial" and similar readings, but such study is in the main done by Western-trained academics and is directed at Western readers in Western journals. $^{6}$

If those academic approaches are abundantly documented, the use of the Bible in African churches or in private African reflection is much less so. How ordinary Africans either at church or at home utilize the Bible is not well researched. ${ }^{7}$

In the mainstream churches, notably Catholic and Anglican, which operate from a lectionary, the use is not greatly different from Catholic or Anglican use in the West; a text (or texts) provide a springboard for reflection on ideas which may in fact be only loosely linked to the text. Also, the frequency of reference to the text or texts varies considerably, with many preachers floating quite clear of the text once launched on their reflection. Africa's evangelical churches (including the evangelical wing of Anglicanism) work the other way; sermons usually begin from a theme (or a series on a theme) adopted independently of the Bible, but during the sermon the preacher will feel bound to refer to biblical texts, often quite frequently. In these cases, the mainline and the evangelical, the same usage is quite recognizable in Western churches.

However, the fastest growing sector of African Christianity is what is often called Pentecostal, and it is the rather new usage characteristic of Pentecostal churches, almost totally ignored in academic discussions, that I will concentrate on in this article. First, though, it is necessary to say

4 Knut Holter, Old Testament Research for Africa: A Critical Analysis and Annotated Bibliography of African Old Testament Dissertations, 1967-2000 (New York: Peter Lang, 2002), 88-9. Thus Dibeela goes so far as to claim that Setswana culture in some important aspects surpasses the Bible (Moiseraele Prince Dibeela, "A Setswana perspective on Genesis 1, 1-10", in West and Dube (eds), Bible in Africa, 384-99).

5 See Paul Gifford, "African theology: observations of an outsider", Hekima Journal, forthcoming.

6 For the potentialities of a postcolonial approach, see Rita Abrahamsen, "African studies and the the postcolonial challenge", African Affairs 102, 2003, 189-210.

7 One of the few such studies is David Tuesday Adamo, "The use of Psalms in African indigenous churches in Nigeria", in West and Dube (eds), Bible in Africa, 336-49, where practices like repeating particular psalms while performing certain rituals are linked to special needs like finding love, passing exams or winning lawsuits. For an example of "socially engaged biblical scholars" to "read with" ordinary Christians (essentially to act as a resource alongside grass-roots Christians) see Gerald O. West, "Contextual Bible study in South Africa: a resource for reclaiming and regainng land, dignity and identity", in West and Dube (eds), Bible in Africa, 595-610. 
something about these churches loosely labelled Pentecostal. They are not necessarily characterized by speaking in tongues, which is the distinguishing mark of classical North American Pentecostal denominations (where tongues are regarded as "initial evidence" of baptism in the Holy Spirit). In Africa they are characterized rather by untrammelled exuberance and participation. Their services consist of equal parts of participative singing (praise and worship) and a lengthy sermon. In Africa, moreover, these churches almost all espouse to a greater or lesser extent a theology of success, power, victory and prosperity. ${ }^{8}$ In these churches the understanding and use of the Bible is coming to be rather distinctive. In mainline churches, the Bible is generally assumed (as in the West) to be a book of revelation which the preacher must expound and apply (though as already noted, the ideas in the sermon may in fact have a rather tenuous link with the text itself). In the new fast-growing Pentecostal sector the Bible is understood as a record of covenants, promises, pledges and commitments between God and his chosen. It is not just a record of covenants and commitments to others in the past. It is not primarily a historical document at all - it is a contemporary document; it tells of God's promises to me. It tells my story; it explains who I am. The Bible is more authoritative on me and my future than what others, or school reports, or medical bulletins, or bank statements, or the visa section of the US embassy, might say of me. The Bible is far more authoritative about me and my destiny than my present circumstances. In the words of Wilfred Lai of Mombasa's Jesus Celebration Centre: "The Bible is God's Word; the Word of God is Covenant. God sealed it with his blood. If God says you are blessed you are blessed, and there's nothing the devil can do about it". ${ }^{9}$ The Bible is covenant and commitment to me, and to me now.

This understanding has led to a distinctive use of the Bible: a performative or declarative use. This use closely exemplifies some of the speech act thinking of Austin: ${ }^{10}$ essentially, one with appropriate authority can, through his use of words, effect what the words say. Thus a judge, in declaring someone innocent, actually brings that about. Likewise, the appropriate authority in declaring war, in pronouncing the Olympic Games open, in conferring an honorary degree, in pronouncing a couple man and wife, actually effects what is said. In the same way, God's promises in scripture are effected in believers' lives through proclamation by an "anointed man of God": the blessings of Abraham, the power of Joseph, the authority of Moses, the sovereignty of David, the miracles of Elijah,

8 I have dealt with this in Paul Gifford, Ghana's New Christianity: Pentecostalism in a Globalising African Economy (London: Hurst \& Co, 2004).

928 May 2006 on Family Praise TV. This is the understanding of Bishop Margaret Wanjiru when she makes a declaration like the following: "From this moment henceforth, you are going to enter into your inheritance, because you are a person of inheritance. Whatsoever you were believing God for shall be fulfilled. Every prayer that you have set before the Lord will be answered. It is done, for the Lord has purposed to do it for his own sake" (Faith Daily, 12-18 November 2005, 9).

10 J. L. Austin, How to Do Things with Words (Cambridge, MA: Harvard University Press, second edition, 1975). 
and increasingly the revival and restoration of Israel itself. The exilic and post-exilic prophecies of restoration (like Isaiah 60) are thus becoming the privileged texts of this Christianity, along with narratives which can be made to illustrate success. If the Old Testament furnishes most material, in the New Testament the Acts of the Apostles is a rich mine, and some of Jesus' miracles. (Millennialism is not a feature of this Christianity, so millennial texts like Daniel or Revelation are not prominent.)

In this article we will consider how this covenant or these promises of scripture (promises of victory, success, hope, achievement) are effected in believers' lives through proclamation. We can illustrate with examples under different headings.

\section{Major biblical narratives}

First, major biblical narratives are proclaimed in this way. Consider Martin Ssuna, pastor of Nairobi's World Harvest Church, using Joshua 3: 7-17 in which, after Joshua tells the people God will drive out the Canaanites, the Hittites, Hivites and so on before them, the Israelites approached the Jordan which stopped its flow and piled up before them; the river was cut off, and the people passed over on dry land. (Ssuna links this with a ritual of washing of the feet.)

You've stepped in disappointments, you've stepped in despondency, you've stepped in betrayal. When they stepped in the waters of the Jordan, the water parted. In other words, God transformed their feet into supernatural makers of roads... . Every office you step into, you can possess; every job you step into you can possess. Every embassy you go to, they can never deny you a visa, because your feet have been washed. You will step in right places; places where you will get benefits. You will step into an office, and they will say: "We have been waiting for you". Order is coming to your life. I will begin to magnify you. You are going to have to stand still, because your pain has to go. The Egyptians will have to go. The Confuse-ites, the Poverty-ites, all the other -ites: Where you gonna step we gonna call it Jordan. You have walked too long, but God is going to lift you up... [We are going to hear testimonies like] "God gave me a car", "God gave me a better job", "God increased my salary". The Jordan that has been resisting you is about to split. The people resisting you are about to split. The moment you step into that water you are a covenant child. Lord, cut off all my enemies, my problems, my poverty, everything that ever hindered me by the power of God. I move from one level to the other, one favour to another... Heap on one side and heap on the other, I'm walking above problems, as a priest of God, I'm walking above all situations. That's why you in World Harvest Church, the banks are about to overflow. I came to tell you today, you are on the brink of a breakthrough. Common sense would say you going to walk on, but you are not going to walk on, you are going to walk into (promotion, job, car dealership); you want a car, they will give it to you, you walk 
into a bank and want money, they will give it to you... It's going to be tough, it's going to be terrible [when you come up tonight for washing of the feet]. It is your right to succeed, it is your right to make it, it is your right to walk in great places. Your unproductive (life?) has been cut off right now. God is cutting off your cycle (of poverty?) as the waters of the Dead Sea [surely Jordan?] were cut off. Shout: "God, cut off for me [shouted five times] any unproductivity, failure, negativity, confusion, lack, in Jesus' mighty name. We have passed over. May this day be a pass-away of sickness, failure, poverty and lack, confusion and terror, generational curses and witchcraft, hindrances in your life! May you walk on (dry) ground! May you run into the favour the anointing of God! Someone say: "I'm crossing over!' [All shout] May this day mark the end of turmoil (and all the -kites be conquered).

Apostle William Mwangangi, of Nairobi's Jesus Manifestation Church, in a broadcast sermon on 3 January 2006, used 1 Samuel 16 about Samuel's finding (or locating) David and anointing him:

This year the anointing of favour will locate you... Jesse had many sons, but the anointing never located them. I am here to prophesy to you today, the anointing of favour will locate you... This year whatever was (holding you back) will promote you. It's the year of God's favour... Money will locate you. You have struggled for years. Today in 2006 it is the end of every struggle the enemy has put on you. It's pay back year. [Reference to locusts.] You just believe the prophetic word from God. This will be manifest in your life. Don't ask how; that is not your (business)... You don't deserve a car, but because of God's favour you will find yourself driving a Mercedes Benz. You don't deserve to buy a bungalow, but because of God's favour you will buy a bungalow; you don't deserve to work in a bank, but because of God's favour you will be working in a bank. The favour of God gives you what you don't deserve to have.

Note that this is very different from mainline and evangelical churches, where the Bible may be only occasionally referred to; here the whole sermon is a ritualized working of the text itself, picking up key words, and playing on them constantly.

\section{Prophetic texts}

Second, not only narratives but major prophetic themes are expounded in this way. In services throughout 2006, it was quite common in Nairobi's Winners' Chapel to read Isaiah 60 antiphonally. ${ }^{11}$

11 Winners' Chapel (full title, Living Faith Church Worldwide Inc.) is a perfect example of Africa's new Christianity (and its use of the Bible). The church was founded in Lagos by David Oyedepo in 1983. It now has over 400 branches in Nigeria and is in forty African countries. It boasts in Lagos the biggest church auditorium in the world, seating 50,400. 
Arise, shine, for your light has come, and the glory of the Lord has risen upon you.

For behold, darkness shall cover the earth and thick darkness the peoples; but the Lord will arise upon you, and his glory will be seen upon you.

And nations shall come to your light, and kings to the brightness of your rising...

Then you shall see and be radiant, your heart shall thrill and rejoice; because the abundance of the sea shall be turned to you, the wealth of the nations shall come to you.

A multitude of camels shall cover you, the young camels of Midian and Ephah; all those from Sheba shall come. They shall bring gold and frankincense, and shall proclaim the praise of the Lord.

All the flocks of Kedar shall be gathered to you, the rams of Nebaioth shall minister to you; they shall come up with acceptance on my altar, and I will glorify my glorious house...

For the coastlands shall wait for me, the ships of Tarshish first, to bring your sons from far, their silver and gold with them, for the name of the Lord your God and for the Holy One of Israel, because he has glorified you...

Your gates shall be open continually; day and night they shall not be shut; that men may bring to you the wealth of the nations, with their kings led in procession.

For the nation and kingdom that will not serve you shall perish; those nations shall be utterly laid waste.

The Glory of Lebanon shall come to you, the cypress, the plane and the pine, to beautify the place of my sanctuary; and I will make the place of my feet glorious.

The sons of those who oppressed you shall come bending low to you; and all who despised you shall bow down at your feet...

Whereas you have been forsaken and hated, with no one passing through, I will make you majestic forever, a joy from age to age...

Instead of bronze, I will bring gold, and instead of iron, I will bring silver. Instead of wood, bronze, instead of stones, iron (and so on).

Here the prophecy of Isaiah is not understood as an historical document, promising blessing to Israel in captivity in Babylon in the sixth century BCE. Perhaps few at Winners' know that the Israelites were ever in exile. Nor is 
anyone concerned about issues of source criticism, identifying the section within the book of Isaiah from which this excerpt is taken. No, this is a promise addressed to the people of Africa; the promised blessings are theirs, and note just how material these blessings are. The ritualized reading actualizes them in their lives.

\section{New Testament narratives}

Third, although this usage is found more in treating Old Testament narratives, we meet it also in the New Testament narratives, including those about Jesus. Consider Martin Ssuna again, preaching on 24 January 2006 on Luke 6: 8, where Jesus tells the man with a withered hand to stand up, and heals him.

Jesus is coming right now. Tonight Jesus is saying stand on your feet. Jesus said, "What are you doing, drunkard, jobless, murderer"... And Jesus said, "Get up!" Jesus said, "I've got power, authority - Get Up!" Jesus is saying to someone: "Get up!" Get up! You have been down, a nobody. Somebody shout, "Get up!" Shout "Up! Up! Up!" [by now the whole congregation is shouting]. Whoever told you you are down, supposed to die, have HIV, cancer... Jesus said: "Get up!" Lift your hands: "I'm up!" Jesus said: "Get up!' Get up from rape, child abuse ... he's calling your house, your business: "Get up!" Are you ready? Your anointing, your favour, your breakthrough is coming! Your husband, wife, uncle has left you: I can hear Jesus saying: "Get up!" Devil, I have strength, power to get up, walk and go home. Shout, "Yes!" Say, "Lord, I am up right now. Lord, every favour you have for me, I'm ready". Receive promotion, favour, prosperity [by now all the congregation are screaming].

Pius Muiru, founder of Kenya's Maximum Miracle Centre, deals with the narrative of Jesus meeting Bartimaeus (Mk 10: 46-52) in which Bartimaeus called to Jesus, Jesus came to a standstill, others rebuked Bartimaeus, but he found a path to Jesus.

I prophesy to you that before two months are over from now, everything will come to a standstill because of you. Some things must come to a standstill in your life until God will give you your miracle. You can no longer be ignored... When Jesus called for Bartimaeus, those that rebuked him helped the blind man to stand up and to clear the way for him. I want you to know that those who are unnecessarily rebuking you and despising you will be [the] same people that God will use to usher you into your place of lifting [sic]. They will make the pathway to your miracle clear. They will see you pass them as you reach out to the miracle awaiting you. There is an anointing in you to overtake those that have been looking down on you. Activate it now! Bartimaeus passed the people that had initially rebuked him as he went to Jesus; he made them see his back! I prophesy to you that this 
year will not be over before the devil sees your back. For when the devil sees your face, it means that your life has taken a beating by the issues of life and therefore you are frustrated. I send a prophetic word to your house that the enemy will not overcome you. I also send a word to your body that diseases will not put you down. Instead, you will conquer them ... Bartimaeus saw again; he received his miracle. You too will see again from that difficult situation that has blinded your progress in life. Your business will see again. What has been robbing your peace has come to an abrupt end; you are not a victim of the devil anymore. ${ }^{12}$

Here is Pius Muiru again, on 18 February 2006, on the story in Acts 12, in which Peter is miraculously led by an angel from prison; the angel disappeared, Peter thought it was a vision, but it was reality; Peter knocked on the door of the Christians; despite the noise, a girl named Rhoda heard, and opened the door.

Somebody's agony is over this morning... There is an anointing this morning to lead you out of your prison situation... The Angel of the Lord leading the way - the angel will lead your way, to rightful spouse, job, ministry, calling. The angel disappears. Peter knew it was not a vision, but a reality. It is a reality that you are cured of HIV, it is a reality that you are cured of alcoholism, it is a reality that there is no more dialysis, it is a reality that opened your connection with the government of the day, it is a reality that those fighting you are (doing so) no longer. There were people praying. Rhoda came. Never again shall you knock at the door and fail to get someone. Never again will you knock at the door and the door will remain shut. From this day on, whenever you shall knock, it shall be opened. From this day on, whenever you shall knock, that door will be opened. The Lord will hear. It doesn't matter the level of joblessness, it doesn't matter the level of political acrimony. As Peter was knocking, Rhoda heard. The Lord says he will cause people to open to you. I speak (this). From this day forward, every door, he will cause it to be opening. The Lord is bringing you to another dispensation. I don't care the demonic noise around. God will cause someone to hear... It is time to take the Word of God for real. Peter knocked at the door, and someone heard. Whenever you are knocking, God will cause someone to hear. It was 3 a.m. I heard the Lord saying to you; it's time to arise; its time to knock. I heard the Lord saying, I will cause men and women, governments and politicians, bishops and politicians, the mighty of the land, to open for you. The door will open!

\section{Less obvious texts}

Fourth, not only are major narratives and themes that might be thought to lend themselves to this treatment used; quite obscure texts or snippets can 
also be pressed into service. Consider Bishop Margaret Wanjiru of Nairobi's Jesus is Alive Ministries on Ezekiel 47: 7-8: "I saw upon the bank of the river very many trees on the one side and on the other. And (the Lord) said to me, 'This water flows toward the eastern region and... when it enters the stagnant waters of the sea, the water will become fresh"'. Bishop Margaret shouts:

Many trees on one side and on the other! [All repeat twice]. Friends, (some say) "We have rest on one side, but still have battles on the other side". But God told me to tell you there will be rest, there will be increase (all the way round). This is the time that Christianity is getting sweeter. There will be rest in marriage, there will be rest in business, there will be rest in church, there will be rest in finances, rest in work and play! All the way round, abundance on this side and on that side [three times]: children, life, church, everywhere. Somebody shout: "It is happening!". Peace on this side, and on that side! Victory on this side, and on that side! Abundance on this side, and on that side! I know it is sometimes preached, "But on one side we will have demons". I hear God saying: "I have decided to bless my people". Lift up those hands and magnify him. He has decided to establish us on this side and on that side! [shouted five times]. [She continues with Ezekiel 47: 9: "Wherever the river flows, every sort of living creature that can multiply shall live, and there shall be abundant fish, for wherever this water comes the sea shall be made fresh']. Everything shall live! So why did you say your marriage died, or your business died? Nothing shall die this season. Fish. What does fish represent?... Fish represents provision. Let there be fish! No, you missed it. Let there be fish [twice; congregation now shouting "Yes!'] Are we reading from the same Bible? Some of you are getting this revelation. There will be a great abundance of fish, says the Bible. According to God's Word, let there be great abundance of fish. Now you can say "Amen!" If the Bible says great number will I be satisfied with one fish? If he says "salary" (will I be satisfied with an ordinary salary? If he says "finance", will I be satisfied with normal finances?). Not one coin, but a great number. If he brings you a great lot, eat one for yourself, and bring us the rest. [She ends the whole sermon with] Tell your neighbour, "I release the waters to come into your life!"13

13 Bishop Margaret on Ezekiel 47: 1-13 is reprinted in Revival Springs, March 2002, 3 7. Bishop Margaret on Job 42: 10 can use the names of Job's daughters performatively: "By the end of (Job's) restoration, he had seven sons and three daughters... Number seven represents perfection, and three represents excellence and fullness of God. "Jemima" means long life, days upon days, or fair as the day. Day refers to light... God says, "This is your day, darkness is over". Tell your neighbour: "Your darkness is over your light has come". Where you were once in darkness and confusion, I say this morning in Jesus' name... Long days mean a long victorious, successful and peaceful life... I don't know if you are sick, today there will be a restoration of your health... The Second daughter Kazer means very pleasant, sweet smell, something precious. You must be washed in precious blood..." and so on. 
In the same way I have heard elaborate sermons on such obiter dicta as "to the other side" (Mk 5:1; 5:12;8:13), with the insistence that "you are crossing to the other side".

\section{Biblical composites}

Fifth, often a raft of biblical motifs are run together and all applied to the congregation in this way. Consider Bishop Margaret's sermon at her October 2005 conference:

Today you are out of the iron furnace, and it cannot hold whatsoever is called by your names. It cannot hold your business, and neither can it hold your career, marriage, children, education or any other thing that belongs to you... because you are out of bondage... All the people that we love and are called by our names, coupled with our finances, are out of the bondage of the fiery furnace. Poverty is destroyed, bankruptcy and destruction is gone - for we are out of the iron furnace... We loose the inheritance of our businesses, the finances, the favour that we need and all the inheritance of our bank accounts - for the Bible declares that what we loose on earth is loosed in heaven, and what we bind on earth too, is in turn bound in heaven. Every blessing that is our inheritance this day, we receive it... The wicked have no authority over our lives. They have no authority to touch our inheritance... All the Dagons have no power, for the presence of the Almighty God is in our lives this day! We bruise the head of the serpent this day, and crush the enemies of our destinies under our feet - to ashes!... We loose our blessings and our money from the west, the east, the south and the north! We bind the Prince of the Air, the Jezebellic Spirit and the Queen of Heaven - and the Queen of the Sea. We cut them off from our lives, out of our finances, abundance and every blessing that belongs to us... We command our heavens to open and declare an overflow of the blessings of God upon our lives. Let the rock of Moses gush out waters that will be more than enough for us; an overflow upon our lives. For every business that belongs unto the children of God, we call forth the customers and the clients that belong to those businesses. We call forth favour so that these clients and customers will be satisfied with the services, through the anointing that we are putting in those businesses... We shall run and not be weary: and we shall soar up like an eagle, because our health has been touched by God's mighty hand... As God glorifies Himself today, he will give us our inheritance as the Abrahamic seed, in the name of Jesus Christ. Our inheritance has come to our bosom! Today is our day of inheritance! If there is anything you and I have been trying to pursue in vain, God is going to ensure that whosoever has them will bring them unto us. ${ }^{14}$

14 Reprinted in her Faith Daily, 5-11 November 2005, 9. Another example from Apostle Ng'anga's Neno Evangelism Centre in Nairobi on 27 August 2006: "I will 
This passage includes references to at least Daniel, Matthew, 1 Samuel, Genesis, Kings, Ephesians, Jeremiah, Exodus and Isaiah. All are indiscriminately run together, considered to apply to the hearers, and declared fulfilled.

\section{Significance}

There are various comments one can make about this performative and declarative use of the Bible. First, it is obvious how misleading it is to call this booming Christianity in Africa "fundamentalist". This is a totally different enterprise, much of which is missed with a label devised for another strain of Christianity altogether. Of course the participants in this Pentecostal explosion would presume the Bible is inerrant, but in what it promises for me, not in what it claims about history or science. This performative approach to the Bible is not anti-critical or even pre-critical the historical approach to the Bible simply does not arise. Nor of course does this use of the Bible exhibit the preoccupations of Africa's professional theologians or Bible scholars; there is no "hermeneutics of suspicion" here, nor any attempt to vindicate African culture considered so attacked by the missionaries and their Bible.

\section{Status of the pastor}

Second, in this whole sector of Pentecostalism this usage is elevating the preacher or pastor to an entirely new level. In the words of Wilfred Lai on 28 May 2006: "I am your Moses. God has sent me to deliver you from everything that has been binding you". A church may come to revolve around its leaders' "prophetic declaration" or "prophetic word". The roots of this phenomenon probably lie in Ezekiel 37: 4-5, where the Lord commands the prophet to "prophesy to these dry bones... and they shall live". These preachers are the contemporary equivalent to an Old Testament prophet. According to this performative usage, scripture is not self-authenticating or self-actualizing. It is the anointed prophet of God who must actualize the biblical promise in your life. In many cases the impression (the very un-Protestant impression) is given that the Bible is the preserve of anointed preachers who can effect it by reason of their gifts. Thus this is one more sign of the non-egalitarian trajectory of so many of these churches. They are becoming increasingly personalized. The pastor in these churches is perhaps best understood as "Effecter of Scripture", presenting himself (and often his wife) as the exemplar of scriptural blessing, and someone you need if you are to realize the scriptural promises in a similar way.

give you a land, build you a house, restore all that the locust has stolen. I am doing a new thing, making a path through the desert. I will cause springs of living water to flow on your desert". There, in just two sentences, are allusions to Genesis, 1 Chronicles, Joel, Isaiah and Ezekiel. 
The obverse side of this declarative or performative ritual is the testimony, in which the recipient of the promise witnesses that the scriptures have indeed been actualized in him or her. This additional ritual is an essential part of this Christianity, and most Pentecostal churches include testimonies in their services, anything from a few to twenty. These testimonies do not centre round deliverance from sin and vice; increasingly they are about the powerful anointing of the preacher through which the blessing has eventuated. This is the case, for example, in almost all of the testimonies at Winners' Chapel. ${ }^{15}$

\section{Biblicized style}

Third, this use of the Bible is increasingly allied to a rhetorical, dramatic, histrionic, participative style. Winners' Chapel is the perfect example of this: all their preachers that I have heard adopt a florid, orotund, repetitive style, very participative, a big secret of the appeal. In fact, this style becomes the crucial factor, remaining biblical in tone while soaring clear of the text itself. Consider some of the declarative statements of Pius Muiru at his September 2006 crusade at Uhuru Park:

You will be a lender not a beggar. This is God's promise to you if you keenly obey his commandments. Through the anointing oil God is going to change your status once and for all. Where you were seen as a financial bother people will now run to you for financial help. Get ready! You will not fall a victim but (instead be) a victor. Satan and circumstances have put you on the run for long. From your contact with this prophetic word I see you become the pursuer and not the pursued. You will punish everything that has afflicted you in the past. The blessings of God shall be permanent and they shall always be retained in your family, through the name of Jesus Christ. Yes, God is ushering you into a permanent place of His blessings. Enough of oscillating between poverty and prosperity. From this day God has permanently changed your status. You are blessed!... International doors shall open up for you. You will soon travel abroad. You've only been a local name. Nobody knows you beyond your immediate neighbourhood but soon your name will be mentioned in high places. Doors that have in the past remained adamantly shut are now opening on their own accord. Walk into them now. Ease is your portion from this hour! Scholarships shall be attained. I see a big banner inscribed "scholarship". God is releasing scholarships to his people right now. Receive yours by faith right now! Exams shall be passed extraordinarily all over the country. A divine enablement is being released upon application of this anointing oil. God is set to surprise every parent who hears this with an unusual performance of his child in KCSE [Kenya Certificate of Secondary Education]. Your family shall not be prone to the deadly HIV infection. A divine cover 
is being released right now. God is hiding His own under His wings and as the scourge spreads you and your family will be exempted. Your family shall not be a victim of jailment [sic] both locally and internationally. Your freedom is established via this prophetic word and the power packed anointing oil. The yoke of serving jail terms for you and your people is removed in Jesus' name. The blood of Jesus shall ensure that you will get more and better things than what you've lost. The future shall and will be better than your past. God is ushering you into a new realm with brand new experience and encounters. The anointing opens to you your palace, just in the same manner as it would do for the anointed Bible-days Kings. There shall be a revival of your dead business! This day marks your day of resurrection! Your business will burst forth in increase! From this hour expect a head-on collision with your financial explosion! God will do this for you! ${ }^{16}$

In Nairobi in 2006 every Winners' service had everyone confessing founder Oyedepo's prophetic word for 2006, a year labelled 'Our Season of Laughter". A pastor read the following, with the congregation shouting "Amen" at the end of every sentence: "In 2006, everything that shall make your laughter complete and total shall be added unto you. The desires of everyone's heart shall be delivered. Every trial shall be turned to testimonies. Every struggle shall be turned to miracles. Every form of barrenness shall be turned to fruitfulness. Every frustration shall be turned to celebration. Every humiliation shall be turned into honour. Every shame shall be turned to glory. And every curse shall be turned into blessings".

Oyedepo's prophetic focus for 2007 was "From Glory to Glory" (2 Cor. 3: 18). The preacher declares: "Our God is an ever forward-leading God. God said to Moses, 'Speak to the children of Israel that they go forward' (Ex. 14: 15). God also speaking in another verse of scripture said, 'I am the Lord, I change not' (Mal. 3: 6)... God is saying about his family, 'Arise ye and depart for this is not your rest' (Mic. 2: 10). God is also saying to us, 'You have gone around this mountain long enough' (Deut. 2: 3). This implies it's time to reach out to the next level of exploits and consequently the next level of glory... God is saying in 2007 I am bringing you out of every shame and reproach into realms of glory you had never thought possible in your life-time. That for your shame you shall have double. That it shall be a year of supernatural restoration of his glory in all areas of our lives. Yea, it shall happen suddenly like most supernatural acts of God in scripture. It shall come like a dream of the night... God is saying to all of us in the Winners' family that the year 2007 is a year of going forward. That we shall be moving from whatever level we are now at to the next. That it shall be your year of restoration of colour. That it shall be your year of restoration of beauty. That it shall be your year of restoration of dignity. That it shall be your year of restoration of glory... You are emerging more than a conqueror in all areas of your life this year. The news of your 
triumphs shall hit the headlines in the course of the year 2007. Therefore arise and shine for your light has finally come."

\section{Bridge to other rituals}

Fourth, there is evidence of this ritual use of scripture being linked with and leading to related rituals, which is all the more surprising because it has traditionally been assumed that Pentecostalism and ritual are mutually exclusive. Pius Muiru, for example, has a most imaginative range of rituals. He conducted a "Land ownership and cleansing crusade" at Uhuru Park in November 2006. He used Deuteronomy 7, 1-7 in which God promised the children of Israel that he would drive away seven mighty nations before them, so they could possess the promised land flowing with abundance. In the same way, Muiru declared, God would drive away all the wrong people standing in the way of land-possession. He listed hindrances to land acquisition: poverty, regressive cultural practices (like prohibitions about women's inheritance), ignorance, generational curses, land disputes, lack of deeds. He then called up eighteen people owning seven acres or more, and prophetically told them to pour some soil onto the ground, symbolizing the freedom to acquire and own land. In "the name of Jesus", he loosed all the chains that bound "the children of God" from acquiring land, and then distributed to those present thousands of small paper bags of sanctified soil to take home and pour on their land and any land which they intended to buy. ${ }^{17}$

Likewise, at the Universal Church of the Kingdom of God in Nairobi, the pastor expounded Luke 17, 1 about scandalizing little ones, and the millstone which is preferable. He drew our attention to a large granite block on the stage, a "millstone". We were told of an exercise in "practical faith". We were to come to the front and take an envelope in which there was a piece of paper and a length of string. We were to write on the paper our areas of greatest danger, and the following Monday the bishop would tie the pieces of paper with the string to the millstone, which he would then drop into the river. Such rituals are increasingly common. ${ }^{18}$

\section{Biblical fundraising}

This explosion of Christianity has had to be paid for - the cars, conventions, buildings, indeed the entire new class of religious professionals - so, fifth, we can note how directly functional this Christianity is for the preachers themselves, because so often it is directly linked to divine fundraising. If you want the biblical promises, you need the anointing of the man or woman of God, and the prophet merits his reward. At Nakuru's

17 Reprinted in Maximum Miracle Times, December 2006, 12-3.

18 The Universal Church of the Kingdom of God is a church of Brazilian origin that is spreading widely in Africa; see Paul Freston, "The Universal Church of the Kingdom of God: a Brazilian church finds success in southern Africa”, Journal of Religion in Africa 35/1, 2005, 33-65. 
Overcomers' Church, the prophet can effect the blessing but he is clear in his teaching: "What must I do to get the blessing?" "The blessing is not free. There is an exchange for it. There is what you give in order for you to receive the blessing...There is a connection between the blessing and tithe". He used Genesis 14: 18-20, the story of Melchizedek, to show that "Abraham gave Melchizedek tithe of all and Melchizedek prophesied the blessing upon him", and even added a final injunction (based on Isaiah 1, 19) to obey willingly: "If you are obedient in your tithes but you give them unwillingly, this won't attract the blessing".

Similarly, the ritual of the millstone just mentioned took place in the context of divine fundraising. God will not move without our tithing; indeed, God seems hamstrung without it. We were invited to the stage to have our wrist tied with a wrist-band inscribed with "O God, Remember that I am a faithful tither", which we could cite in claiming our blessings at the end of the month. And in the envelope in which we wrote our "greatest dangers" to be thrown into the sea with the millstone, we were to enclose money. Those who would enclose 2-5000/- (US\$30-65) were called out first (about ten); then those who would enclose 1000/- (another ten); then those 5-900/-, then those 2-400/- (more going up now), and then 100/-, and finally those "whose enclosure was 'between you and God" (by now all had gone up). In the accompanying prayer it was clear that with our money we were entering a covenant with God.

\section{Personal prophecy}

Sixth, as already noted, this Christianity obviously highlights the significance of the preacher, for his or her gifts seem crucial for the actualizing of the biblical promises. I still think this performative usage is overwhelmingly linked to the preacher, but recently I have met the encouragement to private actualizing. At Winners' in Nairobi on New Year's Day 2007 in a shameless display of merchandising (so again we meet the link to fundraising) we were advised to buy Winners' Chapel bumper stickers for our cars, and other stickers for house windows. Those wanting to own a car this year, or a house, were to buy the stickers and prophesy over them every day: "Every morning before you go to work prophesy to them both, for the son of a prophet is a prophet too". Moreover, "If you want to own ten cars, buy ten stickers, and prophesy over them every day".

\section{Conclusion}

The question of the efficacy of this performative biblical use cannot be avoided. It seems that many of the promises made so indiscriminately cannot be fulfilled. It seems obvious, for example, that most of the members of Nairobi's Winners' Chapel, situated on the border of Kibera, Africa's largest slum, would not own one car, much less ten, by the end of 2007. Winners' in fact is noted for the stark falsifiability of so many of its pledges - to be effected "today", "this morning", "this month", "this year", even 
"immediately after this service". ${ }^{19}$ This in turn raises the question of the way in which these promises are understood. The significant thing is probably the hope engendered. An exclusive and relentless message of hope, assurance, uplift, aspiration, perseverance, with all the accompanying histrionics, rhetorical flourishes, participation, the whole performance supported by superb soloists and choirs, is the distinguishing feature of these churches. Obviously to be told that you matter, you belong at the top, God wants to bring you there, must provide incentives in conditions where it is all too easy to give up. That is the function of this preaching - which, it must be said, it is not very different from the function of the original Hebrew prophets at the time of the exile. This Pentecostal preaching is not expository, nor doctrinal (to illustrate classical Christian doctrines), nor even ethical in the traditional sense. Despite the undeniable tensions inherent in this declarative preaching, it is proving a winning formula and constitutes the most interesting use of the Bible in Africa today. 